\title{
A quantitative test for heat-induced cell necrosis in vascular cambium and secondary phloem of Eucalyptus obliqua stems
}

Yasika Medhavi Subasinghe Achchige ${ }^{1 *}$, Liubov Volkova ${ }^{1}$, Andrew Drinnan ${ }^{2}$ and Christopher J. Weston $^{1}$

1. School of Ecosystem and Forest Sciences, The University of Melbourne, Water Street, Creswick, Victoria 3363, Australia.

2. School of BioSciences, The University of Melbourne, Parkville, Victoria 3010, Australia.

\section{Author Contribution:}

Yasika Medhavi Subasinghe Achchige, Liubov Volkova, Andrew Drinnan and Christopher J. Weston have conceived and designed the experiment. Yasika Medhavi Subasinghe Achchige performed the experiment. Yasika Medhavi Subasinghe Achchige, Liubov Volkova and Christopher J. Weston analysed the data. Andrew Drinnan provided equipment for microscopic analysis. All authors contributed to writing of the manuscript.

*Correspondence: Yasika Medhavi Subasinghe Achchige

4, Water Street, Creswick, Victoria, 3363, Australia

Email: ysubasinghe@student.unimelb.edu.au

Tel: +61353214313, +61 457638732

This article has been accepted For publication And undergone full peer review but has Not been through the copyediting, typesetting, pagination And proofreading process, which may lead to differences between this Version And the Version of Record. Please cite this article as doi: 10.1093/jpe/rtaa081.

(C) The Author(s) 2020. Published by Oxford University Press on behalf of the Institute of Botany, Chinese Academy of Sciences and the Botanical Society of China. All rights reserved. For permissions, please email: journals.permissions@oup.com 


\begin{abstract}
Aims

Exposure of Eucalyptus tree stems to the radiant heat of forest fires can kill cambial cells and their embedded regenerative meristems, thus preventing epicormic resprouting and recovery of the tree. Currently there is no tissue-level method to quantify the viability of cambial cells in Eucalyptus following heat exposure. The first aim of this study was to adapt and validate the tetrazolium reduction method of testing for cell viability in Eucalyptus. The second aim was to apply the method to establish a threshold level of cambium cell viability in Eucalyptus obliqua to enable the identification of a critical temperature.
\end{abstract}

\title{
Methods
}

The study used the tetrazolium reduction method to quantitatively determine phloem-cambium cell viability in Eucalyptus. Circular sections of bark with underlying phloem and cambium were cut from mature Eucalyptus obliqua and samples ranging in mass from $1 \mathrm{mg}$ to $30 \mathrm{mg}$ were exposed for 1 minute to temperature treatments ranging from $20^{\circ} \mathrm{C}$ to $85^{\circ} \mathrm{C}$ and kept for $20-22$ hours at room temperature in $0.8 \% 2,3,5$ triphenyl tetrazolium chloride (TTC) to test for cell viability. The $1,3,5$ triphenyl tetrazolium formazan (TPF) formed was cold extracted with ethanol and quantified as absorbance at $485 \mathrm{~nm}$.

\section{Important findings}

The TTC reduction method reliably quantified a decline in cell viability with rising temperature in tissue sections that included vascular cambium, and identified $60^{\circ} \mathrm{C}$ as the critical temperature for cambium-phloem cells of Eucalyptus species. Cell viability, calculated as [TPF Treatment ${ }^{\circ} \mathrm{C}$ ] / [TPF $20^{\circ} \mathrm{C}$, declined by $90 \%$ between $20^{\circ} \mathrm{C}$ and $85^{\circ} \mathrm{C}$. The cell viability results confirmed that significant tissue necrosis occurred in Eucalyptus at temperatures between $50^{\circ} \mathrm{C}$ and $70^{\circ} \mathrm{C}$, after one minute of in- vitro tissue heating. The decline in cell viability with increasing temperature shown by the TTC method was consistent with an independently derived count of live cells following temperature treatment and neutral red staining.

Key words: cell viability, critical temperature, Eucalyptus, neutral red, 2,3,5 triphenyl tetrazolium chloride. 


\section{Introduction}

In plant cell systems 2,3,5 triphenyl tetrazolium chloride (TTC) is the most commonly used tetrazolium salt to detect the presence of respiring cells, with the number of viable cells directly related to the production of triphenyl tetrazolium formazan (TPF or pink formazan; e.g. Towill and Mazur 1975, Ruf and Brunner 2003). In plants, TTC reduction to TPF has been applied as either a qualitative test staining for live cells (e.g. Pellett and Heleba 1998, Bova and Dickinson 2005) or as a quantitative assay for cell viability (e.g. Steponkus and Lanphear 1967, Towill and Mazur 1975, Caldwell 1993). Among these TTC reduction studies of cell degradation only a few have considered tree tissues (e.g. Clemensson-Lindell 1993, Bova and Dickinson 2005). The latter authors used a tetrazolium staining technique, with the formation of pink formazan in live cells, to indicate the depth of necrosis in heat-treated Acer and Quercus stems subjected to fires - measured with callipers in thin cross sections of trunk removed from the tree after fire.

As far as we are aware there is only one study of heat degradation of tree stem cells based on quantifying TPF production following heat treatments. Dickinson et al. (2004) applied a quantitative test of cell viability to estimate tissue necrosis arising from heat transfer through the bark into the cambium of the northern hemisphere gymnosperms Pinus ponderosa and Pseudotsuga menziesii, and the angiosperms Acer rubrum and Quercus prinus. The quantitative TTC test allowed Dickinson et al (2004) to model stem tissue damage and to predict tissue necrosis and tree mortality after fires.

Given the increasing incidence of fires in forests globally, driven by climate change and increasing anthropogenic ignitions (Ryan and Frandsen 1991, van der Werf et al. 2010, Gričar et al. 2020), it is surprising there are so few detailed studies linking fire characteristics with stem heating and the fate of phloem and cambial cells (e.g. Bova and Dickinson 2005). A better understanding of the specific impacts of fire on tree survival is also highly relevant to the application of prescribed fire that has become important in the management of forests for fuel reduction, regeneration and maintenance of ecological values (McCaw 2013). For example, a better knowledge of the interaction between fuel load, fire-line intensity and bark properties protecting cambium from critical temperatures would allow for more confident specification of planned burn conditions to maximize tree survival (or limit tree mortality). The characteristics of bark, such as thickness and moisture content, directly impact heat transfer to the vascular cambium and the development of lethal temperatures (Vines 1968; Costa et al. 1991; Bova and Dickinson 2004; Jones et al. 2006; Michaletz and Johnson 2007; Lawes et al. 2011; Wesolowski et al. 2014).

When phloem and cambial cells are raised to critical temperatures, often assumed to be $60^{\circ} \mathrm{C}$ (Alexandrov 1964; Wagner 1973), cell viability declines when proteins of the plasma membrane and cytoplasm denature, disrupting enzyme-mediated cell metabolism (Alexandrov 1964; Daniell et al. 1969; Levitt 1956). The death of a large proportion of cambial tissue can limit production of secondary phloem and xylem (Bauer et al. 2010; Bär et al. 2019, Bova and Dickinson 2005; Costa et al. 1991; Reifsnyder et al. 1967), and disrupt water and photosynthate movement (Michaletz and Johnson, 2007). Tree death may follow as root starvation and water stress develop (Kramer and Kozlowski 1960; Nobel 2005). For Eucalyptus, a large genus of trees that dominates Australian forest formations, the elevation of stem cambial tissues to critical temperature may also kill epicormic meristems from which many species regenerate photosynthetic capacity following fire that scorches or removes the tree canopy. 
The genus Eucalyptus includes species of widely-different bark type growing in environments that burn at frequencies from every few years to multiple decades between fires. In Eucalyptus epicormic resprouting is a common regeneration strategy (Keeley et al. 2012; Burrows, 2013), and it is well developed in E. obliqua, the most widely distributed species in south eastern Australia (Brooker and Kleinig 1990, Boland et al. 2006). Although epicormic sprouting is found in numerous families of tree species globally, Eucalyptus is unique because meristems are buried deep in the cambium and protected by the full thickness of the bark, a feature contributing to their description as the world's most successful epicormic resprouters (Clarke et al. 2013). Therefore the development of tissuelevel techniques to determine critical temperature and cell viability in Eucalyptus relates also to regeneration and survival capacity following fire.

According to our knowledge, no previous study has attempted to identify an explicit critical temperature for any woody species. Therefore this study aimed to first adapt and test a TTC method for quantifying phloem and cambial cell viability following heat treatments of tissue sections in vitro. A second aim was to apply the method to establishing a threshold level of cambium cell viability for Eucalyptus obliqua to enable the identification of a critical temperature. According to Dickinson et al (2004) tissues will be killed if cell viability drops by $63.2 \%$. Therefore, the temperature at which the cell viability reaches $36.8 \%$ is considered the critical temperature.

It is anticipated the results of the study will provide rich opportunities for more detailed analysis of relationships between bark characteristics, heat transfer into stems, epicormic regeneration and cambium tissue viability in Eucalyptus more broadly.

\section{Materials and methods}

\section{Approach and experiments}

The first step in developing the TTC test was to identify the minimum mass of phloem-cambial tissue required to confidently characterize the impact of temperature treatments on cell viability. Based on typical sample sizes adopted in previous studies of the TTC test in plant tissues (Dickinson et al. $2004)$, three mass groupings of tissue slices were tested $\left(1 \mathrm{mg}, 10 \mathrm{mg}\right.$, and $30 \mathrm{mg}$ ) at $20^{\circ} \mathrm{C}, 60^{\circ} \mathrm{C}$ and $85^{\circ} \mathrm{C}$ prior to selecting the optimum sample mass to test over more temperature treatments.

According to the results, the $10 \mathrm{mg}$ mass group was selected as the optimum tissue mass for the TCC method.

Furthermore, in the expectation that Eucalyptus cambium-phloem tissue samples contain extractives, such as polyphenols, that may reduce TTC to TPF to give a false positive result for cell viability, we also included an independent measure of cell viability based on staining for live cells with Neutral Red followed by counting, as a cross-check of the magnitude of TTC method results. Subsequently both the TTC method and Neutral Red method were tested on tissue sections at temperatures from $20^{\circ} \mathrm{C}$ to $85^{\circ} \mathrm{C}$ in the expectation of revealing a decline in the cell viability with increasing temperature. A Cell Viability Index (CVI) was calculated as described below. 


\section{Sampling of live-bark and excision of tissue samples}

Sections of bark with underlying phloem, cambium and xylem were obtained from ten, 28-year-old Eucalyptus obliqua L'Hér. var. obliqua trees in Creswick State forest, Victoria, Australia (Latitude:37.42493 , Longitude: 143.90269). A circular window of $8.0 \mathrm{~cm}$ diameter and average depth of $2 \mathrm{~cm}$ containing the bark and the secondary xylem (Fig. 1a) was removed from the stem at $1.3 \mathrm{~m}$ height with a drill-mounted circular cutting tool. Samples were immediately wrapped into a paraffin film to reduce the rate of cell dehydration and transported to the laboratory within 15 minutes and cooled to $4^{\circ} \mathrm{C}$.

After removing the outer bark (phellum) and the xylem, clean cuboids of cambium-phloem cells, about $1 \mathrm{~cm}$ transverse $x 1 \mathrm{~cm}$ radial by $5.0 \mathrm{~cm}$ tangential, were cut with a sharp scalpel blade (Fig. 1b). To identify the optimum mass of sample required for the TTC test, slices of $0.1 \mathrm{~cm}$ thickness but varying transverse and radial lengths (comprised of phloem and cambial cells), ranging from about 1 $\mathrm{mg}$ to $30 \mathrm{mg}$ were hand-cut from the cuboids and immediately transferred to $0.05 \mathrm{M}$ potassium phosphate buffer solution ( $\mathrm{pH}$ 7.4). For the Neutral Red method uni-cellular to bi-cellular thickness transverse cross sections were carefully shaved off from the cuboid and placed in $0.05 \mathrm{M}$ potassium phosphate buffer solution ( $\mathrm{pH}$ 7.2). Both slices and cross sections in the buffer solutions were held at room temperature $\left(20^{\circ} \mathrm{C}\right)$, prior to testing for cell viability by the $\Pi \mathrm{C}$ method and the Neutral Red method (Fig. 1c, Table 1).

\section{Temperature treatments}

The slices and thin cross sections of cambium-phloem tissue samples were placed in plastic vials containing buffer solution and submerged for 1 minute in a continuously stirred water bath held at temperatures from $20^{\circ} \mathrm{C}$ (control) to $85^{\circ} \mathrm{C}$ (positive control); maintained with ice $\left(20^{\circ} \mathrm{C}\right.$ ) or electric element heating $\left(40^{\circ} \mathrm{C}, 50^{\circ} \mathrm{C}, 60^{\circ} \mathrm{C}, 70^{\circ} \mathrm{C}\right.$ and $\left.85^{\circ} \mathrm{C}\right)$. Three slices and five cross sections were tested for each treatment temperature. The temperatures of the solution in the plastic vial and of the water bath were checked during the treatment to confirm consistency. Following the application of temperature treatments, all tissue slices in buffer solution were cooled to $20^{\circ} \mathrm{C}$ prior to assay for cell viability as a function of the mass of formazan produced from TTC according to the method described below. As a check on the cell viability derived from the TTC test, cell viability was also determined by neutral red staining for the same temperature treatments as described further below.

\section{Triphenyl tetrazolium chloride test for cell viability (TTC method)}

Following exposure to heat treatments the tissue slices were placed in vials containing $1.5 \mathrm{ml}$ of $0.8 \%$ tetrazolium chloride (TTC) solution prepared in $0.05 \mathrm{M}$ potassium phosphate buffer $(\mathrm{pH} 7.4$; (Chen et al. 1982)), vacuum infiltrated for six cycles of 15 seconds each and kept at room temperature $\left(20^{\circ} \mathrm{C}\right)$ for $20-22$ hours in the dark. Samples were then rinsed twice with deionized water, blot dried, macerated using a mortar and pestle, transferred to Falcon ${ }^{\mathrm{TM}}$ conical tubes containing $4 \mathrm{ml}$ of $95 \%$ ethyl alcohol, vortexed for 30 seconds and kept in $95 \%$ ethyl alcohol for 1216 hours to allow formazan extraction at room temperature $\left(20^{\circ} \mathrm{C}\right)$. The supernatant was then centrifuged at $3000 \mathrm{rpm}$ for 5 minutes and the absorbance at $485 \mathrm{~nm}\left(\mathrm{~A}_{485}\right)$ was measured using a UV-1800 spectrophotometer (SHIMADZU ${ }^{\mathrm{TM}}$, Japan). The formazan concentration was calculated from the standard curve (Fig. S1). The macerated tissue remaining in the Falcon ${ }^{\mathrm{TM}}$ tubes was then 
oven dried to $70^{\circ} \mathrm{C}$ for 12 hours to allow the mass of formazan formed to be reported on a sample dry weight basis. The CVI was calculated by dividing the formazan concentration for each temperature treatment by the mean formazan concentration of the samples kept at $20^{\circ} \mathrm{C}$.

$\mathrm{CVI}(\mathrm{TTC}$ method $)=\frac{\begin{array}{c}\text { Formazan concentration of } \\ \text { the treated slice }\end{array}}{\begin{array}{c}\text { Mean formazan concentration of } \\ \text { the slices kept at } 20^{\circ} \mathrm{C}\end{array}} \quad$ Eqn 1

\section{Neutral red staining test for cell viability (Neutral Red method)}

Following temperature treatments, the thin cross sections were transferred to freshly prepared neutral red (3-amino-7-dimethylamino-2-methylphenazine hydrochloride, Toluylene red) solution $(20 \mathrm{ppm})$, made up in a $0.05 \mathrm{M}$ potassium phosphate buffer $(\mathrm{pH} 7.2)$ and vacuum infiltrated for 30 seconds for consistent staining (Dickinson and Johnson, 2004). Tissue sections were steeped in the stain for 1 hour and then washed with distilled water to remove background residual stain prior to microscopy. Cell staining was observed with slides of tissue sample mounted in a compound light microscope set at magnification of $\times 40$ (XSP-103a, Xiamen Phio Scientific Instruments Co. Ltd., China). Three field view counts of live (red stained) phloem parenchyma cells and cambial cells were selected from the entire cross section based on minimal cell damage and even staining. Cells stained as light red were counted as live and unstained cells were counted as dead cells, with the total cell count per field view then scaled to 100 (Fig. 2). Phloem fibres were not counted, nor were ray parenchyma cells which stained dark red, whether live or dead, most likely due to the presence of tannin (Chattaway 1953). The arrangement of cambial and phloem cells in cross sections influenced the total cell count, with both the size of the bundles and the number of bundles varying among each field view (Chattaway 1953). Moreover, due to the arrangement and the size of ray parenchyma in a transverse section (Chattaway 1953), they occupy more space in a field view but contain fewer cells than other phloem parenchyma. In contrast, owing to the multiseriate tangential arrangement of the non-ray parenchyma in a transverse section (Chattaway 1953), there are more cells per unit area compared to ray parenchyma. Therefore, considering the arrangement of cells in the phloem tissue, cross sectioning may damage most phloem parenchyma cells, thereby affecting the live cell count relative to the total cell count, and producing a lower live cell percentage than anticipated. Thus, the total cell count per field view was scaled to 100 and the live cell count was recalculated accordingly.

The CVI for each field view was calculated by dividing the number of live cells for each field view by the mean number of live cells in the samples exposed to $20^{\circ} \mathrm{C}$ treatment.

CVI (Neutral Red method $)=\frac{\begin{array}{c}\text { Live cell count of } \\ \text { each field view }\end{array}}{\text { Mean live cell count of }}$

Eqn 2

Following the findings of Dickinson et al (2004) this study assumed that a loss of $63.2 \%$ or more of cell viability would kill the cambium-phloem tissue sample. Therefore a CVI=0.368 ( $\approx 0.37)$ was taken as the threshold $C V I$ value for this study and the temperature at $C V I=0.37$ is identified as the critical temperature. 


\section{Statistical Analysis}

Due to heteroscedastic distribution of the residuals of the CVI of each method, all CVI values were log transformed prior to statistical analysis. The effect of temperature on cell viability was assessed using one-way analysis of variance (ANOVA) followed by a Tukey post-hoc test of GenStat 18.1 (VSN International Ltd, Hemel Hempstead, UK). Linear regression models were developed to identify the relationship between temperature and CVI. These models were used to determine the critical temperature according to each of the two methods.

\section{Results}

\section{Optimum tissue mass for TTC method and comparison of TTC and Neutral Red methods}

For each sample mass grouping $\left(1 \mathrm{mg}, 10 \mathrm{mg}, 30 \mathrm{mg}\right.$ ) the $\mathrm{A}_{485}$, and hence TPF or formazan formation, increased from lowest in the $85^{\circ} \mathrm{C}$ treatments, through $60^{\circ} \mathrm{C}$ to highest in the $20^{\circ} \mathrm{C}$ treatments (Fig. 3). Within the $1 \mathrm{mg}$ sample mass group, $\mathrm{A}_{485}$ did not vary significantly between temperature treatments, while $10 \mathrm{mg}$ and $30 \mathrm{mg}$ sample mass groups provided sufficient TPF formation to significantly separate temperature treatments (Table S1). The $A_{485}$ for $85^{\circ} \mathrm{C}$ treated cells increased with sample mass, indicating an absorbance associated with heat-killed tissues (Fig. 3; $\left.r^{2}=0.95\right)$. This increasing production of TPF as the mass of dead cells increased from $1 \mathrm{mg}$ to $30 \mathrm{mg}$ may be due to TTC reduction by cambium-phloem tissue extractives such as polyphenols (Clemensson-Lindell 1993). This result shows that background reduction of TTC needs to be accounted in calculating cell viability. For further testing of the TTC method, a sample mass of around $10 \mathrm{mg}$ was selected as this minimized sample preparation time, especially at the maceration step, whilst also providing sufficient mass to separate temperature treatments.

\section{The change in the CVI with increasing temperature treatments}

The cell viability index was negatively linearly correlated with temperature $(p<0.001)$ according to results from both methods for measuring cell viability (Fig. 4). For the TTC method the CVI declined by $63.2 \%$ at $60.1^{\circ} \mathrm{C}\left(\approx 60^{\circ} \mathrm{C}\right)$, while for the neutral red method the CVI declined by $63.2 \%$ at $82.5^{\circ} \mathrm{C}\left(\approx 83^{\circ} \mathrm{C}\right)$ (Fig. 4$)$.

In the TTC method, the $\mathrm{CVI}$ of samples kept at $20^{\circ} \mathrm{C}(1.000 \pm 0.104)$ was ten times greater than samples treated at $85^{\circ} \mathrm{C}(0.114 \pm 0.006)$ (Fig. 4); comparisons among all temperatures for significant differences in formazan concentration are shown in Table 2.

Similarly, in the Neutral Red method the highest mean CVI $(0.994 \pm 0.033)$ was observed in the control $\left(20^{\circ} \mathrm{C}\right)$ tissue samples and the lowest $(0.348 \pm 0.023)$ was recorded in the positive control $\left(85^{\circ} \mathrm{C}\right.$ ) tissue samples, while cell viability gradually decreased from $40^{\circ} \mathrm{C}$ to $70^{\circ} \mathrm{C}$ (Fig. 4, Table 3). In the Neutral Red method, the CVI decreased by about $40 \%$ from $20^{\circ} \mathrm{C}$ to $60^{\circ} \mathrm{C}$ and by $65 \%$ at $85^{\circ} \mathrm{C}$. The mean $\mathrm{CVI}$ of each temperature treatment (excluding $50^{\circ} \mathrm{C}$ and $60^{\circ} \mathrm{C}$ ) was significantly different from all the other temperature treatments $(p<0.001)$.

When compared to the cell viability of the control samples of the TTC method, results depict a loss of nearly $50 \%$ of cell viability when reaching $50^{\circ} \mathrm{C}$, a loss of $60 \%-80 \%$ of cell viability when reaching 
$60^{\circ} \mathrm{C}-70^{\circ} \mathrm{C}$, and a loss of nearly $90 \%$ of cell viability when reaching $70^{\circ} \mathrm{C}-85^{\circ} \mathrm{C}$. In addition, there is no significant difference between the mean $\mathrm{CVI}$ at $70^{\circ} \mathrm{C}$ and $\mathrm{CVI}$ at $85^{\circ} \mathrm{C}$ (Table 2).

\section{Discussion}

The TTC method optimized in this study consistently identified in a quantitative way the gradual decrease in cell viability with increasing temperature and yielded reproducible CVI's for Eucalyptus phloem-cambium tissues. The cell viability reached a minimum at around $70^{\circ} \mathrm{C}$ as treatment temperature increased from $20^{\circ} \mathrm{C}$, similar to the results of studies by Chen et al (1982); Caldwell (1993); Dickinson and Johnson (2004) and Dickinson et al (2004).

The results of this study suggest $60^{\circ} \mathrm{C}$ (TTC method) as the critical temperature for cambium-phloem cells of Eucalyptus species. This finding broadly supports the idea of critical temperature, which is often assumed to be $60^{\circ} \mathrm{C}$ in previous studies by Alexandrov (1964), van Wagner (1973), Bauer et al, (2010), Dickinson and Johnson (2004) and Dickinson et al (2004). According to our knowledge no prior study has provided sufficient evidence to establish $60^{\circ} \mathrm{C}$ as the critical temperature for woody cambium-phloem cells. Therefore this study marks the first successful attempt to establish a threshold temperature for cambium-phloem cell viability following heat exposure.

The decline in TPF production with increasing temperature demonstrates the utility of the TTC method as an indicator of cell viability in Eucalyptus cambium-phloem tissues, as there is good evidence from the literature that phloem parenchyma cell viability is seriously impaired at $60^{\circ} \mathrm{C}$, with no cells surviving at $85^{\circ} \mathrm{C}$ (Dickinson et al. 2004).

Prolonged exposure to temperatures below $60^{\circ} \mathrm{C}$ can also cause cambium death leading to tree mortality (Dickinson and Johnson, 2004). Because temperature and exposure time each affect the degree of loss of cell viability (Chen et al. 1982), it is necessary to investigate interactions between them to gain the most detailed understanding of controlling factors (Hare 1961; Kayll 1963,

Dickinson et al. 2004). Identification of critical exposure time will also allow for better comparisons of the cambium-phloem cell viability of different Eucalyptus species and to estimate their level of heat tolerance.

We selected a $10 \mathrm{mg}$ tissue mass group for the TTC method because a lower rather than a higher tissue mass reduces sample preparation time, especially the maceration step, allowing the consistent application of temperature treatments, whilst also minimizing potential interference from polyphenols (Steponkus and Lanphear 1967; Clemensson-Lindell 1993). The TTC method is technically simple, facilitating many samples to be tested for CVI over 24 hours in robust experimental designs. It also allows for cambium-phloem samples to be taken from tree trunks subjected to heating in both laboratory conditions and from field environments, and tested for CVI so that the insulating properties of bark can be quantified.

We note that the Neutral Red method for assessing viability of the cambium cells of Eucalyptus species confirmed the same trend in results as the TTC method but yielded higher average CVI than the TTC method at each treatment temperature, except for $20^{\circ} \mathrm{C}$ (Fig. 4 and Fig. S2), suggesting that the critical temperature derived $\left(83^{\circ} \mathrm{C}\right)$ from the Neutral Red method is an overestimation. This may result from human error in differentiating live and dead cells when the underlying cell layer stained in red, so that the dead top-most layers appeared to be alive. In this way, the Neutral Red method 
requires consistent and accurate preparation of thin sections, preferably of unicellular or bicellular layers; the method is thus more technically demanding and more prone to human error than the TTC method.

In E. obliqua the epicormic meristem is deeply embedded in the cambium, a rare characteristic in woody species. In most commercially important families of tree species the meristem is located on the surface of the bark with no epicormic trace extending through the xylem to the pith. This includes Pinus, the subject of most of the detailed cell death studies (Stone and Stone 1954, Waring and Pitman, 1985, Ryan and Reinhardt 1988, Finney 1999, Fowler et al. 2004, Gucker 2007, Pausas and Keeley 2014). In Eucalyptus, bark plays a significant role in protecting the epicormic meristems from heat-related death during fire (McArthur, 1967, Gill and Ashton, 1968, Nicolle 2006, Clarke et al. 2013, Burrows et al. 2010, Wesolowski et al. 2014). Because bark slows the rate of heat transfer, it protects the vascular cambium from overheating that can cause cell death (Gill and Ashton 1968; Odhiambo et al. 2014). Insulation capacity increases with the thickness, density and moisture content of the bark (Wesolowski et al. 2014), so that tree diameter and height, fire history, and recent climate all become important in fire survival (Brando et al. 2012, Wesolowski et al. 2014).

\section{Conclusion}

In this study we developed a fast and reliable method to test cambium cell viability of Eucalyptus via a Cell Viability Index (CVI) following heat exposure, using the 2,3,5 - triphenyl tetrazolium chloride (TTC) method. We found that a $10 \mathrm{mg}$ sample of tissue is the optimal mass for preparation of a sample while providing consistent application of temperature treatments. The study revealed that $60^{\circ} \mathrm{C}$ is the explicit critical temperature for cambial cells of Eucalyptus. The developed method and CVI can be applied in further studies to investigate heat and exposure time interactions of cambium viability in Eucalyptus species. 


\section{Funding}

Authors received no funding for this study.

\section{Acknowledgments}

Authors acknowledge Dr Lisa Wittick for sharing the spectrophotometer, Rajitha Ratnayake for field and technical assistance during project implementation. Yasika Subasinghe Achchige acknowledges the Melbourne Research Scholarship from The University of Melbourne.

\section{Statement of Conflict of Interest}

Authors declare no conflict of interest 


\section{References}

Alexandrov VY (1964) Cytophysiological and Cytoecological Investigations of Heat Resistance of Plant Cells Toward the Action of High and Low Temperature. Q Rev Biol 39:35-77.

Bauer G, Speck T, Blomer J, et al. (2010) Insulation capability of the bark of trees with different fire adaptation. J Mater Sci 45:5950-5959.

Bär A, Michaletz ST, Mayr S (2019) Fire effects on tree physiology. New Phytologist 223:1728-1741.

Boland DJ, Brooker I, Chippendale GM, et al. (2006) Forest Trees of Australia. 5th ed. CSIRO Publishing.

Bova A, Dickinson M (2005) Linking surface-fire behavior, stem heating, and tissue necrosis. Can J For Res 35:814-822.

Brando PM, Nepstad DC, Balch JK, et al. (2012) Fire-induced tree mortality in a neotropical forest: the roles of bark traits, tree size, wood density and fire behaviour. Glob Change Biol 18:630-641.

Brooker MIH and Kleinig DA (1990) Field guide to eucalypts: south-eastern Australia. Inkata Press, Melbourne, Vic.

Burrows GE, Hornby SK, Waters DA, et al. (2010) A wide diversity of epicormic structures is present in Myrtaceae species in the northern Australian savanna biome- implications for adaptation to fire. Aust J Bot 58:493-507. 
Caldwell CR (1993) Estimation and analysis of cucumber (Cucumis sativus L.) Leaf cellular heat sensitivity. Plant physio 101:939-945.

Chattaway M (1953) The anatomy of bark I: The genus Eucalyptus. Aust J Bot 1:402-433.

Chen HH, Shen ZY, Li P (1982) Adaptability of crop plants to high temperatures stress. Crop Sci 22:719-725.

Clarke PJ, Lawes MJ, Midgley JJ, et al. (2013) Resprouting as a key functional trait: how buds, protection and resources drive persistence after fire. New Phytol 197:19-35.

Clemensson-Lindell A (1994) Triphenyl tetrazolium chloride as an indicator of fine-root vitality and environmental stress in coniferous forest stands: Applications and limitations. Plant Soil 159:297-300.

Costa J, Oliveira L, Viegas D, et al. (1991) On the temperature distribution inside a tree under fire conditions. Int J Wildland Fire 1:87-96.

Daniell JW, Chappell WE, Couch HB (1969) Effect of sublethal and lethal temperature on plant cells. Plant physio 44:1684-1689.

Dickinson MB, Johnson EA (2004) Temperature-dependent rate models of vascular cambium cell mortality. Can J For Res 34:546-559.

Dickinson MB, Jolliff J, Bova A (2004) Vascular cambium necrosis in forest fires: using hyperbolic temperature regimes to estimate parameters of a tissue-response model. Aust J Bot 52:757-763.

Finney MA (1999) Mechanistic modeling of landscape fire patterns. in: DJ Mladenoff and WL Baker, editors. Spatial modeling of forest landscape change: approaches and applications. Cambridge Press, Cambridge, United Kingdom.

Fowler JF, Sieg CH (2004) Post fire mortality of ponderosa pine and Douglas-fir: a review of methods to predict tree death. USDA Forest Service General technical report RMRS-GTR-132. Rocky Mountain Research Station, Fort Collins, Colorado, USA.

Gill A, Ashton DH (1968) The role of bark type in relative tolerance to fire of three central Victorian eucalypts. Aust J Bot 16:491-498. 
Gričar J, Hafner P, Lavrič M, et al. (2020). Post-fire effects on development of leaves and secondary vascular tissues in Quercus pubescens, Tree Physiology 40:796-809.

Gucker CL (2007) Pinus rigida . In Fire Effects Information System. US Department of Agriculture. http://www.fs.fed.us/ database/feis/

Hare RC (1961) Heat effects on living plants. Forest Service, Southern Forest Experiment Station, USDA.

Jones JL, Webb BW, Butler BW, et al. (2006) Prediction and measurement of thermally induced cambial tissue necrosis in tree stems. Int $J$ Wildland Fire 15:3-17.

Kayll A (1963). Heat tolerance of Scots pine seedling cambium using tetrazolium chloride to test viability. Canada, Department of Forestry Publication.

Keeley JE, Bond WJ, Bradstock RA, et al. (2012) Fire in Mediterranean Ecosystems: Ecology, Evolution and Management. Cambridge University Press.

Kramer PJ, Kozlowski TT (1960) Physiology of trees. USA: McGraw-Hill Book Co. Inc.

Lawes MJ, Richards A, Dathe J, et al. (2011) Bark thickness determines fire resistance of selected tree species from fire-prone tropical savanna in north Australia Plant Ecol 212:2057-2069.

Levitt J (1956) The hardiness of plants. USA: Academic Press Inc.

McArthur AG (1967) Fire behaviour in eucalypt forest. Forestry and Timber Bureau, Canberra.

McCaw WL (2013) Managing forest fuels using prescribed fire - A perspective from southern Australia. Forest Ecol Manag 294:217-224.

Michaletz ST, Johnson EA (2007) How forest fires kill trees: a review of the fundamental biophysical processes. Scand J For Res 22:500-515. 
Nicolle D (2006) A classification and census of regenerative strategies in the eucalypts (Angophora, Corymbia and Eucalyptus-Myrtaceae), with special reference to the obligate seeders. Aust J Bot 54:391-407.

Nobel PS (2005) Physicochemical and environmental plant physiology. USA: Elsevier Academic Press.

Odhiambo B, Meincken M (2014) The protective role of bark against fire damage: a comparative study on selected introduced and indigenous tree species in the Western Cape, South Africa.

Pausas JG, Keeley JE (2014) Evolutionary ecology of resprouting and seeding in fire-prone ecosystems. New Phytol 204:55-65.

Pellett NE, Heleba DA (1998) Comparing callus growth with discoloration and electrical conductivity as measures of stem injury after freezing woody plants. J Am Soc Hortic Sci 123:826-831.

Reifsnyder WE, Herrington LP, Splat KW (1967) Thermophysical properties of bark of shortleaf, longleaf, and red pine. Yale School of Forestry \& Environmental Studies Bulletin Series, 80 .

Ruf M, Brunner I (2003) Vitality of tree fine roots: re-evaluation of the tetrazolium test. Tree Physio 23:257-263.

Ryan KC, Frandsen WH. (1991) Basal injury from smoldering fires in mature Pinus ponderosa Laws. Int J Wildland Fire 1:107-118.

Ryan KC, Reinhardt ED (1988) Predicting post fire mortality of seven western conifers. Canadian Journal of Forest Research 18:1291-1297.

Steponkus PL, Lanphear FO (1967) Refinement of the triphenyl tetrazolium chloride method of determining cold injury. Plant physio 42:1423-1426.

Stone E, Stone M (1954) Root collar sprouts in pine. J For 52:487-491 
Towill LE, Mazur P (1975) Studies on the reduction of 2, 3, 5-triphenyltetrazolium chloride as a viability assay for plant tissue cultures. Can J Bot 53:1097-1102.

van der Werf GR, Randerson JT, Giglio L, et al. (2010) Global fire emissions and the contribution of deforestation, savanna, forest, agricultural, and peat fires (1997-2009). Atmos Chem Phys 10:11707-11735.

van Wagner CEV (1973) Height of Crown Scorch in Forest Fires. Canad J For Res 3: 373378.

Vines R (1968) Heat transfer through bark, and the resistance of trees to fire. Aust J Bot 16:499-514.

Waring RH, Pitman GB (1985) Modifying lodgepole pine stands to change susceptibility to mountain pine beetle attack. Ecology 66:889-897.

Wesolowski A, Adams MA, Pfautsch S (2014) Insulation capacity of three bark types of temperate Eucalyptus species. Forest Ecol Manag 313:224-232. 


\section{Tables}

Table 1: Summary of sample volume and sample preparation for TTC method and Neutral Red method

\begin{tabular}{lcc}
\hline \multicolumn{1}{c}{ Specifications } & TTC method & Neutral Red method \\
\hline $\begin{array}{l}\text { Sample size }(\mathrm{cm} 3) \text { (Approximately) } \\
\text { Length }(\mathrm{cm}) \times \text { Width }(\mathrm{cm}) \times \text { Thickness }(\mathrm{cm})\end{array}$ & $\begin{array}{l}0.025 \\
(0.5 \times 0.5 \times 0.1)\end{array}$ & $\begin{array}{c}0.009 \\
(0.3 \times 0.3 \times 0.01)\end{array}$ \\
$\begin{array}{l}\text { Number of tissue samples per treatment } \\
\text { Total number of tissue samples }\end{array}$ & 3 & 150 \\
Temperatures $\times$ No of tissues $\times$ No of trees & $(6 \times 3 \times 5)$ & $(6 \times 5 \times 5)$ \\
pH value of the buffer solution & & 7.2 \\
$\begin{array}{l}\text { Heat exposure time for each treatment temperatures } \\
\text { (minutes) }\end{array}$ & 1 & 1 \\
\hline
\end{tabular}


Table 2: Comparison of cell viability among different treatment temperatures in the TTC method

\begin{tabular}{ccccccc}
\hline & $20^{\circ} \mathrm{C}$ & $40^{\circ} \mathrm{C}$ & $50^{\circ} \mathrm{C}$ & $60^{\circ} \mathrm{C}$ & $70^{\circ} \mathrm{C}$ & $85^{\circ} \mathrm{C}$ \\
\hline $20^{\circ} \mathrm{C}$ & - & - & - & - & - & - \\
$40^{\circ} \mathrm{C}$ & $\mathrm{NS}$ & - & - & - & - & - \\
$50^{\circ} \mathrm{C}$ & $* * *$ & $* *$ & - & - & - & - \\
$60^{\circ} \mathrm{C}$ & $* * *$ & $* * *$ & $\mathrm{NS}$ & - & - & - \\
$70^{\circ} \mathrm{C}$ & $* * *$ & $* * *$ & $* * *$ & $* * *$ & - & - \\
$85^{\circ} \mathrm{C}$ & $* * *$ & $* * *$ & $* * *$ & $* * *$ & $\mathrm{NS}$ & \\
\hline
\end{tabular}

NS-non-significant; significance level: ${ }^{*}<0.05,{ }^{* *}<0.01,{ }^{* * *}<0.001$ 
Table 3: The average ( \pm s.e., $n=25$ ) of cells counted in a field view according to status - live, dead, tannin filled and the average CVI for Neutral Red method

\begin{tabular}{lcccc}
\hline $\begin{array}{c}\text { Treatment } \\
\text { temperature }\end{array}$ & $\begin{array}{c}\text { Average of live } \\
\text { cells }\end{array}$ & $\begin{array}{c}\text { Average of } \\
\text { dead cells }\end{array}$ & $\begin{array}{c}\text { Average of tannin } \\
\text { filled cells }\end{array}$ & $\begin{array}{c}\text { Average Cell } \\
\text { Viability Index }\end{array}$ \\
\hline $20^{\circ} \mathrm{C}$ & $50 \pm 0.3$ & $46 \pm 0.2$ & $4 \pm 0.4$ & $0.99 \pm 0.03$ \\
$40^{\circ} \mathrm{C}$ & $40 \pm 0.2$ & $55 \pm 0.4$ & $5 \pm 0.3$ & $0.80 \pm 0.05$ \\
$50^{\circ} \mathrm{C}$ & $33 \pm 0.5$ & $57 \pm 0.4$ & $10 \pm 0.3$ & $0.66 \pm 0.05$ \\
$60^{\circ} \mathrm{C}$ & $30 \pm 0.3$ & $60 \pm 0.5$ & $10 \pm 0.4$ & $0.60 \pm 0.03$ \\
$70^{\circ} \mathrm{C}$ & $21 \pm 0.4$ & $70 \pm 0.2$ & $8 \pm 0.4$ & $0.43 \pm 0.02$ \\
$85^{\circ} \mathrm{C}$ & $17 \pm 0.5$ & $73 \pm 0.4$ & $10 \pm 0.5$ & $0.35 \pm 0.02$ \\
\hline
\end{tabular}




\section{Figure Legends}

Figure 1: (a) A circular bark window, (b) Cuboid sample, (c) Cross sections (Top) and slices (Bottom) in the respective buffer solution

Figure 2: Microscopic image of a cross section of a stained secondary phloem tissue of $E$. obliqua. CM-cambium, DC- dead cell, FC-false live cell, LC-live cell, PF-phloem fibres, PS-phloem sieve tube

Figure 3: Formazan concentration produced at each treatment temperature vs dry weight of the tissue samples, where Size 1 is $1 \mathrm{mg}$, Size 2 is $10 \mathrm{mg}$, Size 3 is $30 \mathrm{mg}(\mathrm{n}=18)$

Figure 4: Effect of increasing temperature on cell viability. Upright closed triangles are mean live cell percentages (Neutral Red method) and closed circles are mean formazan concentrations (TTC method), for number of samples in each of the methods see Table 1. The horizontal dashed-line represents the $0.37 \mathrm{CVI}$. The interception points of the horizontal dashed-line and linear regression lines indicate the critical temperature derived from each method. Error bar is the standard error of the mean 


\section{Figures}

Figure 1: (a) A circular bark window, (b) Cuboid sample, (c) Cross sections (Top) and slices (Bottom) in the respective buffer solution

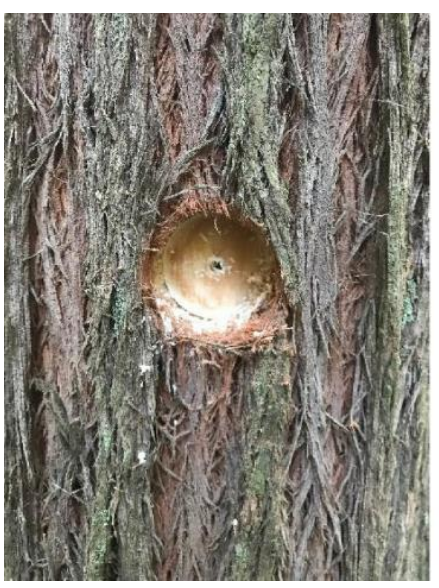

(a)

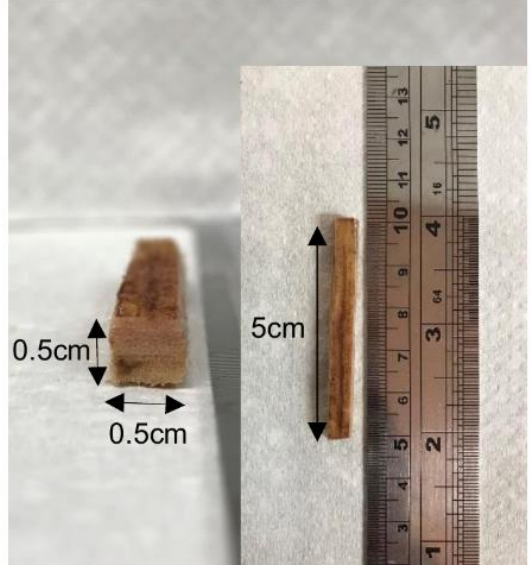

(b)

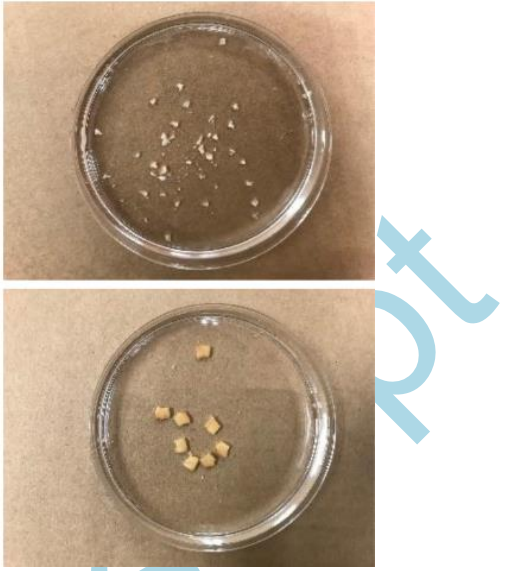

(c) 
Figure 2: Microscopic image of a cross section of a stained secondary phloem tissue of E. obliqua. CM-cambium, DC- dead cell, FC-false live cell, LC-live cell, PF-phloem fibres, PSphloem sieve tube

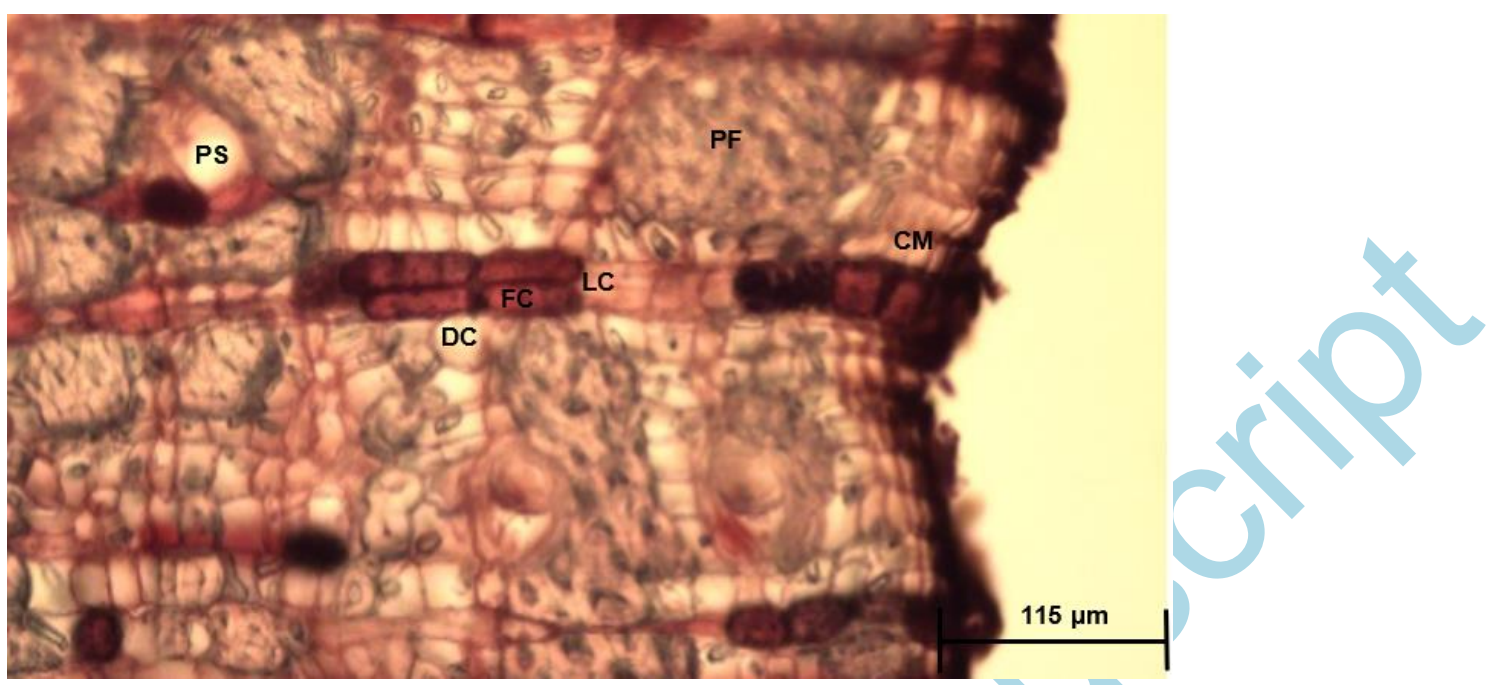


Figure 3: Formazan concentration produced at each treatment temperature vs dry weight of the tissue samples, where Size 1 is $1 \mathrm{mg}$, Size 2 is $10 \mathrm{mg}$, Size 3 is $30 \mathrm{mg} \quad(\mathrm{n}=18)$

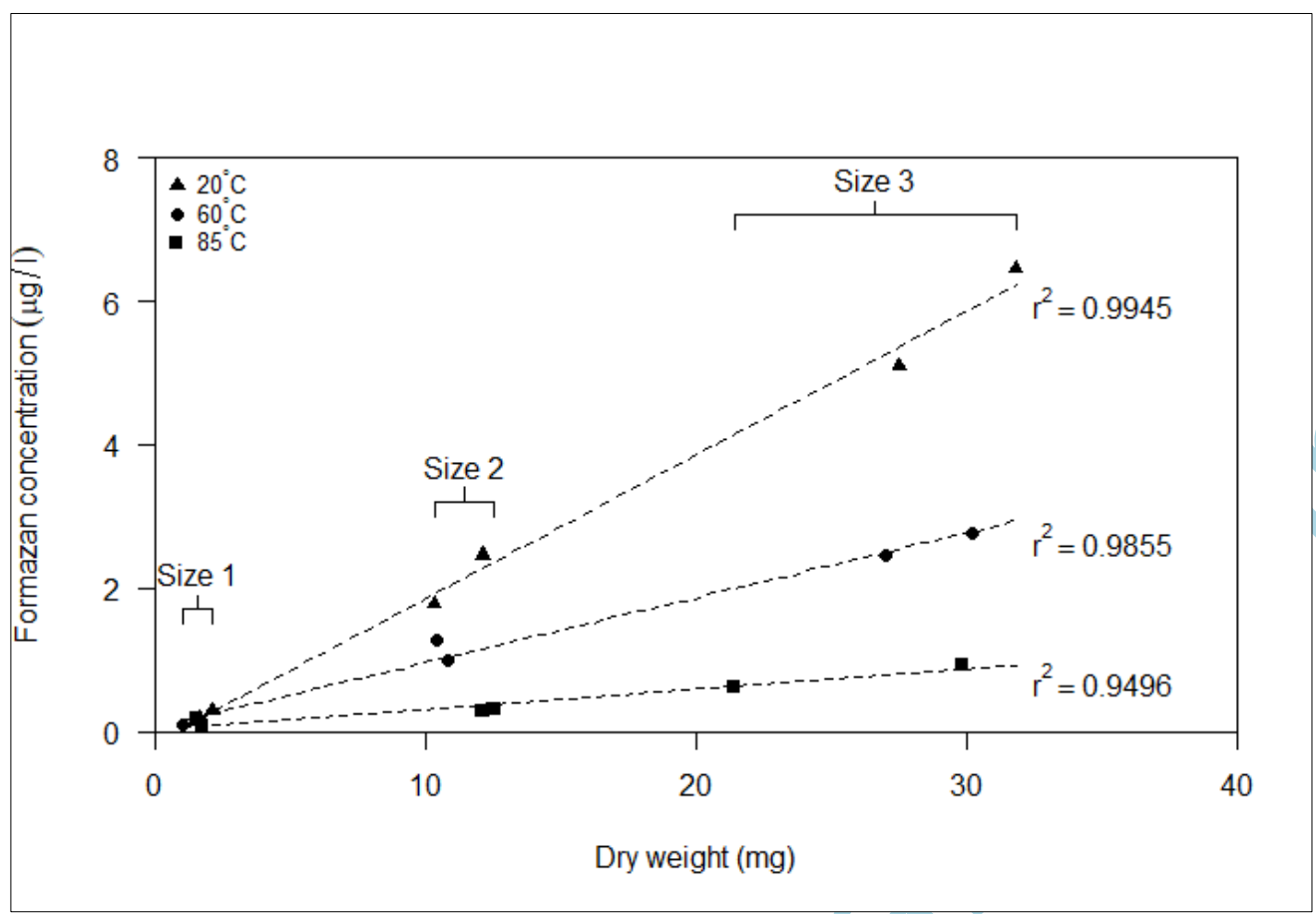


Figure 4: Effect of increasing temperature on cell viability. Upright closed triangles are mean live cell percentages (Neutral Red method) and closed circles are mean formazan concentrations (TTC method), for number of samples in each of the methods see Table 1 . The horizontal dashed-line represents the $0.37 \mathrm{CVI}$. The interception points of the horizontal dashed-line and linear regression lines indicate the critical temperature derived from each method. Error bar is the standard error of the mean

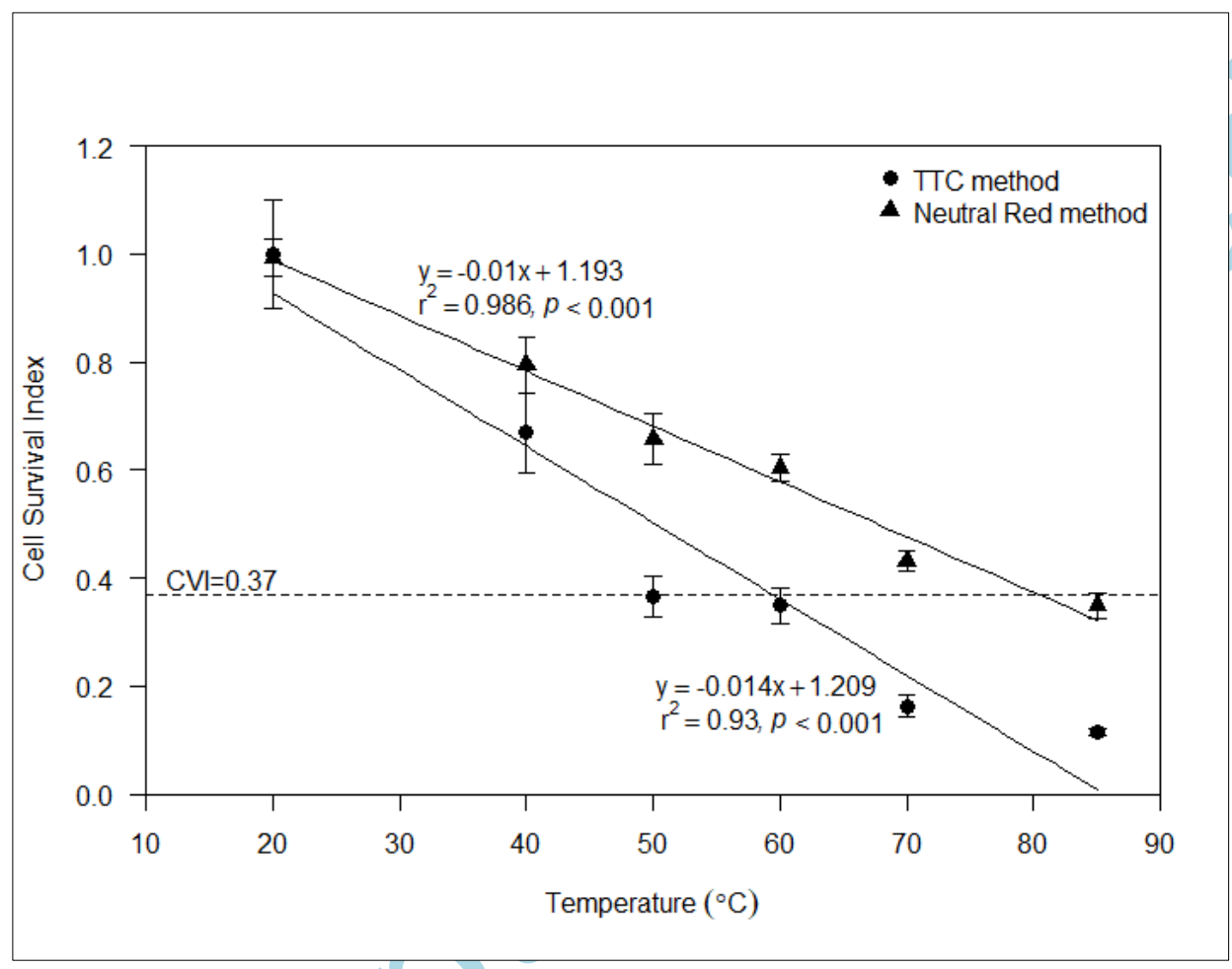




\section{University Library}

\section{- M M N E R VA A gateway to Melbourne's research publications}

Minerva Access is the Institutional Repository of The University of Melbourne

Author/s:

Achchige, YMS;Volkova, L;Drinnan, A;Weston, CJ

Title:

A quantitative test for heat-induced cell necrosis in vascular cambium and secondary phloem of Eucalyptus obliqua stems

Date:

2021-02-01

\section{Citation:}

Achchige, Y. M. S., Volkova, L., Drinnan, A. \& Weston, C. J. (2021). A quantitative test for heat-induced cell necrosis in vascular cambium and secondary phloem of Eucalyptus obliqua stems. JOURNAL OF PLANT ECOLOGY, 14 (1), pp.160-169. https:// doi.org/10.1093/jpe/rtaa081.

Persistent Link:

http://hdl.handle.net/11343/258505 